\title{
METHODOLOGY OF TRAINING COORDINATING EXERCISES OF YOUNG SCHOOLCHILDREN WITH THE PSYCHIC DEVELOPMENT DELAY AT LESSONS OF PHYSICAL TRAINING
}

\author{
Oleg Tuchak \\ Department of Human Health Physical Therapy \\ Lesia Ukrainka East European National University \\ 13 Voli ave., Lutsk, Ukraine, 43025 \\ tu4ka_v_nebe@ukr.net \\ Viktor Romaniuk \\ Department of Sports-Mass and Tourism Activities \\ Lesia Ukrainka East European National University \\ 13 Voli ave., Lutsk, Ukraine, 43025 \\ romanukviktor96@gmail.com
}

\begin{abstract}
There has been elaborated the methodology of training coordinating exercises of young schoolchildren with the psychic development delay at lessons of physical culture. It consists of two blocks - psychic and physical ones. The psychic block includes the following processes and properties: visual and aural memory; image-logic and ocular-activity thinking. The physical one consists of the following coordinating qualities: the ability to evaluation and regulation of dynamic and temporal movement parameters, orientation in space; static and dynamic balance. Means, used at realizing the methodology, were divided in general and special ones. A peculiarity of special means was conditions of their realization, chosen in such a way to favor the development of coordinating abilities, psychic processes and properties most effectively. A component of the author methodology is a protocol of complex evaluation of the development level of coordinating abilities, psychic processes and properties of young schoolchildren with the psychic development delay. The forming study has proved the effectiveness of the experimental methodology. There were revealed statistically reliable changes in involuntary operational visual and aural memory, image-logic and visual-activity thinking. The ability to evaluation and regulation of dynamic and temporal movement parameters, static and dynamic balance improved.
\end{abstract}

Keywords: psychic development delay, coordinating exercises, methodology, young school age.

\section{Introduction}

Children with the psychic development delay (PDD) are for today a special link that needs increased attention of specialists [1]. According to data, they are from 12 to $18 \%$ of the general number of ones that enter the first form of a secondary school [2]. This fact testifies the acute nen cessity in searching for new approaches for solving this problem.

The analysis of literary sources testified that for today several aspects of correction of the schoolchildren's psychic development delay are studied. Especially, the methodology of physical activities for teenagers with PDD is scientifically grounded [3]. Organization-methodical bases of using moving games in physical education of young schoolchildren with PDD are studied [4]. Methods of correction of memory parameters in 6-year children with PDD were elaborated [5]. An integrative correcting-developing model of rehabilitation and adaptation of children with peculiarities of psychophysical development was created [6]. Age and individual psychosomatic peculiarities of young schoolchildren and teenagers as predictors of rational development are studied [7].

At the same time, elucidation of separate sides of the studied problem, complex researches with grounding the methodology of training coordinating exercises of young schoolchildren as an effective way of correction of the psychic development delay are absent. 


\section{Aim of research}

To substantiate theoretically and to check experimentally the methodology of training coordinating exercises of young schoolchildren with the psychic development delay at lessons of physical culture.

\section{Materials and methods of research}

The following research methods were used for attaining this aim:

- theoretical - analysis of psychological-pedagogical, special literature and documentary sources, comparison, systematization of information (for argueding initial statements of the research, generalizing existent data, substantiating the essential content of node notions);

- empirical - testing of the development level of coordinating abilities and psychic processes and properties (for studying the influence of the elaborated methodology of young schoolchildren with PDD); theoretical modeling, pedagogical experiment (ascertaining, forming) - for developing the learning-methodological support of training coordinating exercises and revealing the effectiveness of the offered methodology;

- statistical - for processing empirical data, for checking the reliability of obtained results by methods of mathematical statistics.

The research was realized during 2012-2016 in four stages:

- analytical-ascertaining stage (2012-2013) provided the analysis of psychological-pedap gogical, scientific methodological literature on the problem of the psychic development delay of young schoolchildren; determination of an object, subject, aim, tasks, programs of the research; accumulation and systematization of the empirical material;

- searching stage (2013-2014) - determination of the state of the development of coordinating abilities of psychic processes and properties in young schoolchildren with the psychic development delay and their interconnections; formation of structural components of the author methodology of training coordinating exercises of young schoolchildren with the psychic development delay at lessons of physical culture;

- forming stage (2014-2015) was in implementation of the author methodology of training coordinating exercises of young schoolchildren with the psychic development delay and verification of its effectiveness;

- generalizing stage (2015-2016) provided the analysis, generalization of data of results of probation of the methodology of training coordinating exercises of young schoolchildren with the psychic development delay at lessons of physical culture, making conclusions and predicting further prospects of the study.

The research-experimental work was realized on the base of Lutsk training-rehabilitation center (experimental group - 29 persons). The control group included 30 pupils.

\section{Results}

The study of preconditions of the methodology of training coordinating exercises of young schoolchildren with the psychic development delay revealed the problem of development of coordinating abilities, psychic processes and properties in modern young schoolchildren with PDD. In general it was established, that studied qualities, processes and properties are at the low development level. There was revealed the heterogeneity of groups by parameters: each age group included pupils with the higher development level and with the very low one.

Especially, the study of abilities to spatial orientation was realized using running to 5 numbered filled balls. It was established, that the statistically reliable difference between parameters of the ability to spatial orientation is absent between schoolchildren of all classes of control and experimental groups (Table 1).

Pupils from the second control class ran to numbered filled balls in $16.7 \mathrm{~s}$, their coevals from the experimental group - in $16.8 \mathrm{~s}$. Third-formers' results in the control group were $20.6 \mathrm{~s}$, in experimental one $-21.2 \mathrm{~s}$. Fourth-formers of the control group executed the test in $14.3 \mathrm{~s}$, their coevals from the experimental group in $15.7 \mathrm{~s}$. 
Table 1

The state of coordinating abilities in young schoolchildren with the psychic development delay

\begin{tabular}{|c|c|c|c|c|c|c|c|c|}
\hline Group & $\mathbf{n}$ & $\mathbf{X}$ & $\mathbf{S}$ & $\mathbf{S x}$ & $\mathrm{V} \%$ & $\pm \%$ & $\mathbf{t}(\mathbf{U})$ & $\mathbf{P}$ \\
\hline \multicolumn{9}{|c|}{ Agility indices of second-formers } \\
\hline Control & 16 & 12.73 & 1.28 & 0.33 & 10.05 & \multirow{2}{*}{6.68} & \multirow{2}{*}{-1.014} & \multirow{2}{*}{$>0.05$} \\
\hline Experiment & 10 & 13.58 & 2.45 & 0.82 & 18.04 & & & \\
\hline \multicolumn{9}{|c|}{ Agility indices of third-formers } \\
\hline Control & 7 & 13.56 & 1.68 & 0.69 & 12.39 & \multirow{2}{*}{2.21} & \multirow{2}{*}{-0.347} & \multirow{2}{*}{$>0.05$} \\
\hline Experiment & 9 & 13.86 & 1.76 & 0.62 & 12.70 & & & \\
\hline \multicolumn{9}{|c|}{ Agility indices of fourth-formers } \\
\hline Control & 9 & 10.35 & 1.07 & 0.38 & 10.34 & \multirow{2}{*}{18.84} & \multirow{2}{*}{-2.773} & \multirow{2}{*}{$<0.01$} \\
\hline Experiment & 11 & 12.3 & 2.01 & 0.64 & 16.34 & & & \\
\hline \multicolumn{9}{|c|}{ Spatial orientation indices of second-formers } \\
\hline Control & 15 & 16.65 & 2.65 & 0.71 & 15.92 & \multirow{2}{*}{-0.60} & \multirow{2}{*}{$71^{(\mathrm{U})}$} & \multirow{2}{*}{$>0.05$} \\
\hline Experiment & 10 & 16.75 & 2.75 & 0.92 & 16.42 & & & \\
\hline \multicolumn{9}{|c|}{ Spatial orientation indices of third-formers } \\
\hline Control & 6 & 20.56 & 3.77 & 1.69 & 18.34 & \multirow{2}{*}{3.11} & \multirow{2}{*}{-0.281} & \multirow{2}{*}{$>0.05$} \\
\hline Experiment & 8 & 21.2 & 4.74 & 1.79 & 22.36 & & & \\
\hline \multicolumn{9}{|c|}{ Spatial orientation indices of fourth-formers } \\
\hline Control & 9 & 14.31 & 2.15 & 0.76 & 15.02 & \multirow{2}{*}{9.36} & \multirow{2}{*}{$45^{(\mathrm{U})}$} & \multirow{2}{*}{$>0.05$} \\
\hline Experiment & 10 & 15.65 & 5.65 & 1.88 & 36.10 & & & \\
\hline \multicolumn{9}{|c|}{ Static balance indices of second-formers } \\
\hline Control & 14 & 14.18 & 8.69 & 2.41 & 61.28 & \multirow{2}{*}{3.81} & $615^{(\mathrm{U})}$ & $>005$ \\
\hline Experiment & 10 & 14.72 & 9.7 & 3.23 & 65.90 & & 01.5 & -0.00 \\
\hline & & Static balan & dices of thi & ormers & & & & \\
\hline Control & 6 & 11.32 & 21.52 & 9.62 & 190.11 & 54.77 & $27^{(\mathrm{U})}$ & $>0.05$ \\
\hline Experiment & 8 & 5.12 & 4.07 & 1.54 & 79.49 & & & \\
\hline & & Static balanc & dices of fou & ormers & & & & \\
\hline Control & 8 & 29.84 & 20.91 & 7.90 & 70.07 & 6260 & 2256 & $<005$ \\
\hline Experiment & 11 & 11.16 & 12.36 & 3.91 & 110.75 & 02.00 & 2.250 & \\
\hline & & ynamic balar & ndices of se & 1-form & & & & \\
\hline Control & 15 & 10.40 & 2.96 & 0.79 & 28.46 & 106 & 0106 & $>005$ \\
\hline Experiment & 10 & 10.29 & 2.21 & 0.74 & 21.48 & 1.00 & 0.100 & 0.03 \\
\hline & & Dynamic bala & indices of $t$ & forme & & & & \\
\hline Control & 6 & 12.08 & 4.40 & 1.97 & 36.42 & 1301 & 0621 & $>005$ \\
\hline Experiment & 8 & 13.76 & 5.72 & 2.16 & 41.57 & 15.01 & -0.021 & -0.00 \\
\hline & & ynamic bala & ndices of fo & -forme & & & & \\
\hline Control & 9 & 8.89 & 3.11 & 1.10 & 34.98 & 810 & 0.510 & 05 \\
\hline Experiment & 9 & 8.17 & 2.87 & 1.01 & 35.13 & 0.10 & 0.510 & -0.03 \\
\hline
\end{tabular}

Note: (U) - U-Mann-Whitney criterion for comparing the difference between two independent samples with the distribution, distinct from the standard one; ( $\mathrm{N})$ - data group with the distribution, distinct from the standard one

The analysis of the variation coefficient indicates that all six studied groups cannot be called homogenous, according to results of spatial orientation testing. As far as the variation coefficient was within $15-36 \%$, it, in its turn, indicates the fact that the ability of schoolchildren's spatial orid entation essentially differed by the development level within the mentioned age groups.

Evaluation of testing results of spatial orientation, according to standards, present in literature [8] testifies the very low development level of this ability in young children with PDD. Only 
one of average results of all tested classes approached to standards. Especially, in fourth-formers from the control group the average result was $14.3 \mathrm{~s}$ that corresponds to the sufficient development level of first-formers. Such result testifies the essential lag of children with PDD from standards by the development level of spatial orientation.

At the same time the improvement of a series of coordinating qualities, psychic processes and properties with age in young schoolchildren with PDD was revealed. Taking into account this positive dynamics, one can state that coordinating qualities, psychic processes and properties of the studied contingent are developing.

The study of peculiarities of correlations between coordinating qualities, psychic processes and properties established that the more complicated coordinating quality, the more number of coordinating qualities, psychic processes and properties correlates with it. So, the development level of more number of qualities determines it [9].

The obtained results of the studies have proved our hypothesis about the close correlation between coordinating qualities, psychic processes and properties of children. It gave the reason to suppose that the development of coordinating qualities may favor the improvement of psychic processes and properties of children with PDD. The theoretical background of this statement is a scientific conception about the unity of the organism as an integral system, where all components are closely interconnected and mutually conditioned $[10,11]$.

So, the further studies were directed on elaboration and theoretical substantiation of the effectiveness of the methodology of training coordinating exercises of young schoolchildren with the psychic development delay at lessons of physical culture. The experimental methodology is based on the state learning program on physical training for secondary educational institutions (1-4 classes).

The author methodology of training coordinating exercises of young schoolchildren with the psychic development delay is directed on achieving the main aim - optimization of the physical and psychic development of young schoolchildren with PDD. Achieving this aim provides the solution of two interconnected tasks: the development of coordinating abilities; the development of psychic processes and properties.

The methodology structure can be conventionally divided in two blocks - psychic and physical ones. The first (psychic) block includes the following processes and properties: memory (visual and aural); (thinking) image-logic and ocular-activity. The physical (second) one consists of the following coordinating qualities: agility (the ability to evaluation and regulation of dynamic and temporal movement parameters, orientation in space); balance (static and dynamic). Both blocks are the single whole of the pedagogical process of children with PDD, their separation at realizing the experimental methodology is conventional.

Means, used at realizing the methodology, were divided in general and special ones. General means include: theoretical knowledge; general gymnastics; moving games and attractions; elements of light athletics; general developing exercises; elements of self-massage. Each group of the general means is divided in subgroups that, in their turn, consist of special means. The typical feature of special means is their execution conditions. They all are selected in such a way for favor the development of coordinating abilities, psychic properties and processes most effectively.

A component of the author methodology is criteria of complex evaluation of the development level of coordinating abilities, psychic processes and properties young schoolchildren with PDD. Psychic processes and properties are evaluated by the parameters: of visual and oral memory; image-logic and ocular-activity thinking. The evaluation of coordinating abilities is realized using indices of the dynamic and temporal moving parameters, spatial orientation, static and dynamic balance. The following tests are used for that: "Remember pictures", "Remember words", "Seasons", "Cut out little figures", "Shuttle running $3 \times 1 \cdot \mathrm{m} »$, «Running to 5 numbered balls", "Bondarevsky's methodology" and "Turns on a gymnastic bench".

The evaluation is realized by quantitative (marks) and qualitative (verbal) indicators. The quantitative system of evaluation provides a 5-point scale for each quality. All quantitative testing results are added for the complex evaluation of the child development level. 
The qualitative evaluation criteria are verbal evaluations such as "Well", "Very well", "Fairly well" and "Fantastically" that correspond to a certain quantitative mark. A teacher at lessons used only qualitative evaluation in the direct with schoolchildren. The quantitative evaluation is used for controlling the state of coordinating abilities, psychic properties and processes, their dynamics.

The study of the influence of the experimental methodology on coordinating abilities, psychic properties and processes of young schoolchildren with PDD established its higher effectiveness comparing with a conventional one (Table 2).

Table 2

Coordinating abilities of young schoolchildren with the psychic development delay under conditions of the experimental methodology

\begin{tabular}{|c|c|c|c|c|c|c|c|c|c|c|c|}
\hline Group & $\mathrm{n}$ & $\mathbf{X}$ & $\mathbf{S}$ & Sx & $\mathrm{V} \%$ & $\pm \%$ & $t(T)$ & $\mathbf{P}$ & $\pm \%$ & $t(U)$ & $\mathbf{P}$ \\
\hline \multicolumn{12}{|c|}{ Agility indices of second-formers } \\
\hline Control & 13 & 11.84 & 1.12 & 0.32 & 9.46 & 6.99 & 1.936 & $>0.05$ & \multirow{2}{*}{1.44} & \multirow{2}{*}{0.326} & \multirow{2}{*}{$>0.05$} \\
\hline Experiment & 8 & 12.01 & 1.08 & 0.41 & 8.99 & 11.56 & 2.220 & $<0.05$ & & & \\
\hline \multicolumn{12}{|c|}{ Agility indices of third-formers } \\
\hline Control & 6 & 11.24 & 1.29 & 0.58 & 11.48 & 17.11 & 2.718 & $<0.05$ & \multirow{2}{*}{5.16} & \multirow{2}{*}{0.740} & \multirow{2}{*}{$>0.05$} \\
\hline Experiment & 9 & 11.82 & 1.50 & 0.53 & 12.69 & 14.72 & 2.609 & $<0.05$ & & & \\
\hline \multicolumn{12}{|c|}{ Agility indices of fourth-formers } \\
\hline Control & 11 & 10.37 & 1.47 & 0.46 & 14.18 & 0.19 & 0.032 & $>0.05$ & \multirow{2}{*}{6.27} & \multirow{2}{*}{$42^{(\mathrm{U})}$} & \multirow{2}{*}{$>0.05$} \\
\hline Experiment & 12 & 11.02 & 1.11 & 0.33 & 10.07 & 10.41 & 2.246 & $<0.05$ & & & \\
\hline \multicolumn{12}{|c|}{ Spatial orientation indices of second-formers } \\
\hline Control & 13 & 15.48 & 2.39 & 0.69 & 15.44 & 7.03 & 1.191 & $>0.05$ & \multirow{2}{*}{3.20} & \multirow{2}{*}{0.580} & \multirow{2}{*}{$>0.05$} \\
\hline Experiment & 8 & 15.00 & 1.21 & 0.46 & 8.07 & 10.45 & $3^{(\mathrm{T})}$ & $<0.05$ & & & \\
\hline \multicolumn{12}{|c|}{ Spatial orientation indices of third-formers } \\
\hline Control & 6 & 18.17 & 3.59 & 1.61 & 19.76 & 11.62 & 1.040 & $>0.05$ & \multirow{2}{*}{2.73} & \multirow{2}{*}{0.300} & \multirow{2}{*}{$>0.05$} \\
\hline Experiment & 9 & 18.68 & 1.56 & 0.55 & 8.35 & 11.89 & 2.217 & $<0.05$ & & & \\
\hline \multicolumn{12}{|c|}{ Spatial orientation indices of fourth-formers } \\
\hline Control & 11 & 13.41 & 2.42 & 0.77 & 18.05 & 6.29 & 0.833 & $>0.05$ & \multirow{2}{*}{1.94} & \multirow{2}{*}{$48^{(\mathrm{U})}$} & \multirow{2}{*}{$>0.05$} \\
\hline Experiment & 12 & 13.15 & 1.76 & 0.53 & 13.38 & 15.97 & $13^{(\mathrm{T})}$ & $<0.05$ & & & \\
\hline \multicolumn{12}{|c|}{ Static balance indices of second-formers } \\
\hline Control & 13 & 17.81 & 10.14 & 2.93 & 56.93 & 25.60 & $35^{(\mathrm{T})}$ & $>0.05$ & 440 & $55(\mathrm{U})$ & $>005$ \\
\hline Experiment & 8 & 18.61 & 2.03 & 0.77 & 10.91 & 26.43 & 2.220 & $<0.05$ & 4.49 & 55 & $>0.05$ \\
\hline & & Stati & oalanc & ndices & third- & rmers & & & & & \\
\hline Control & 6 & 14.70 & 12.61 & 5.64 & 85.78 & 29.86 & $16^{(\mathrm{T})}$ & $>0.05$ & 3137 & $28(\mathrm{U})$ & $>005$ \\
\hline Experiment & 9 & 11.19 & 5.35 & 1.89 & 47.81 & 118.55 & 2.383 & $<0.05$ & 31.31 & 28 & $>0.05$ \\
\hline & & Static & alance & dices $\mathrm{C}$ & fourth- & prmers & & & & & \\
\hline Control & 11 & 28.63 & 17.41 & 5.51 & 60.81 & -4.05 & 0.141 & $>0.05$ & 2502 & 125 & $>005$ \\
\hline Experiment & 12 & 21.21 & 7.11 & 2.14 & 33.52 & 90.05 & 2.790 & $<0.05$ & 25.92 & 1.25 & -0.00 \\
\hline & & Dynam & balanc & indices & f secon & -former & & & & & \\
\hline Control & 13 & 9.04 & 2.97 & 0.86 & 32.85 & 13.08 & 1.144 & $>0.05$ & 763 & 0.678 & $>005$ \\
\hline Experiment & 8 & 8.35 & 1.45 & 0.55 & 17.37 & 18.85 & 2.312 & $<0.05$ & 1.05 & 0.070 & 0.00 \\
\hline & & Dynan & balan & indice & of thirc & formers & & & & & \\
\hline Control & 6 & 8.99 & 2.78 & 1.24 & 30.92 & 25.58 & 1.547 & $>0.05$ & 1272 & 25 (U) & $>005$ \\
\hline Experiment & 9 & 10.30 & 1.98 & 0.70 & 19.22 & 25.15 & 2.444 & $<0.05$ & 12.12 & 25 & -0.00 \\
\hline & & Dynam & balan & indice & f fourt & former & & & & & \\
\hline Control & 11 & 10.12 & 4.20 & 1.33 & 41.50 & 13.84 & 0.685 & $>0.05$ & 2065 & $44^{(\mathrm{U})}$ & $>005$ \\
\hline Experiment & 12 & 8.03 & 1.15 & 0.35 & 14.32 & 1.71 & 0.204 & $>0.05$ & 20.05 & & $>0.05$ \\
\hline
\end{tabular}

Note: $(T)$ - Wilcoxon T-criterion that helped to compare depending samples with the distribution, differed from the standard one 
In experimental classes there were observed more essential, statistically reliable changes in coordinating abilities, psychic properties and processes of young schoolchildren with PDD. At the same time we can talk about the certain effectiveness of the conventional methodology, because some positive changes were revealed also in control classes.

Visual memory reliably improved in average in three experimental classes by $19 \%$, aural by $55 \%$, image-logic thinking by $25 \%$, agility and distinctness of ocular-activity thinking by $24 \%$ and $23 \%$ respectively. Control classes didn't demonstrate any statistically reliable changes at the tendency to improving visual and aural memory by $7 \%$ and $24 \%$, image-logic thinking by $14 \%$, speed and distinctness of ocular-activity thinking by $5 \%$ and $12 \%$.

The average increments of agility in experimental classes were $12 \%$, spatial orientation ability $-13 \%$, static balance $-77 \%$ and dynamic balance $-16 \%$. There were not observed any statistically reliable changes of coordinating qualities in control classes. There was revealed the general tendency to improving agility by $13 \%$, spatial orientation by $8 \%$, static balance by 16 and dynamic balance by $17 \%$.

The analysis of the dynamics of heterogeneity of groups by the variation coefficient also showed the effectiveness of the author methodology. During the research period variations of all studied parameters decreased in experimental groups, in control ones any reliable changes were not revealed. The variation of coordinating abilities decreased in experimental groups in average from $48 \%$ to $18 \%$, and psychic properties and processes from $39 \%$ to $14 \%$.

According to the developed protocol of the complex evaluation of coordinating abilities, psychic properties and processes of young schoolchildren with PDD there was revealed the improvement of their development under conditions of the experimental study. The development level improvement from the up-intermediate to advanced one was observed in second-formers, whereas the development level of the studied qualities was from the pre-intermediate to intermediate one in third-formers. The development level of the studied qualities of fourth-formers was intermediate with the positive dynamics of the total number of marks during the study (Table 3).

Table 3

The protocol of complex evaluation of the development level of coordinating abilities, psychic properties and processes of fourth-formers with PDD

complex evaluation of the development level of coordinating abilities, psychic properties and processes of fourth-formers with PDD

N. S. of a studied person

\begin{tabular}{|c|c|c|c|c|c|c|c|c|c|}
\hline \multirow{2}{*}{\multicolumn{2}{|c|}{$\underset{1}{\text { Parameter }}$}} & \multicolumn{5}{|c|}{ Points } & \multirow{2}{*}{\multicolumn{2}{|c|}{ Mark/sum of points }} & \multirow{2}{*}{$\begin{array}{c}\text { Development } \\
\text { level }\end{array}$} \\
\hline & & 2 & 3 & 4 & 5 & & & & \\
\hline 1 & Visual memory, amount & 5 & 6 & 7 & 8 & 9 & $4(4)$ & & \\
\hline 2 & Aural memory, amount & 4 & 5 & 6 & 7 & 8 & $3(2)$ & & \\
\hline 3 & $\begin{array}{l}\text { Image-logic thinking, } \\
\text { points }\end{array}$ & 6 & 7 & 8 & 9 & 10 & $3(2)$ & & $\leq 11$ low \\
\hline 4 & $\begin{array}{l}\text { Speed of ocular-activity } \\
\text { thinking, min }\end{array}$ & 8.0 & 7.0 & 6.0 & 5.0 & 4.0 & $4(3)$ & & $\begin{array}{l}12-22 \text { pre- } \\
\text { intermediate }\end{array}$ \\
\hline 5 & $\begin{array}{l}\text { Distinctness of ocular- } \\
\text { activity thinking, points }\end{array}$ & 6 & 7 & 8 & 9 & 10 & $3(2)$ & $30(26)$ & $\begin{array}{c}23-33 \\
\text { intermediate }\end{array}$ \\
\hline 6 & Agility, s & 13.5 & 12.4 & 11.3 & 10.2 & 9.1 & $3(2)$ & & 34-44 up- \\
\hline 7 & Spatial orientation, $\mathrm{s}$ & 18.8 & 16.4 & 14.0 & 11.7 & 9.3 & $3(2)$ & & intermediate \\
\hline 8 & Static balance (right), s & 2 & 12 & 23 & 34 & 45 & $2(1)$ & & 45-55 advanced \\
\hline 9 & Static balance (left), s & 1 & 11 & 20 & 30 & 39 & $3(2)$ & & \\
\hline 10 & Dynamic balance (right), s & 14 & 12 & 10 & 7 & 5 & $3(3)$ & & \\
\hline 11 & Dynamic balance (left), s & 14 & 12 & 9 & 7 & 5 & $4(3)$ & & \\
\hline
\end{tabular}

\section{Discussion}

This study testifies the firstly elaborated and substantiated effectiveness of the methodology of training coordinating exercises of young schoolchildren with the psychic development delay at 
lessons of physical culture. The statistical analysis has proved its more effectiveness comparing with the conventional one, used at physical education of children with PDD.

This study widened and added the state learning program of physical culture for 2-4 form pupils with the psychic development delay. The typical feature of the author methodology is the fact that it favors the improvement of involuntary operational visual and aural memorizing, image-logic and ocular-activity thinking of young schoolchildren with PDD by developing coordinating abilities.

The study added data about the methodology of physical activities of pupils with PDD [3]. At the same time, from our point of view, the study of the contingent of young schoolchildren is more important in the practical aspect, because just this age is sensitive for the development of coordinating abilities, psychic properties and processes. Data about memory correction of 6-year children with PDD by means of physical education are also added [5]. Besides memory, our study includes image-logic and ocular-activity thinking. The more age diapason of children is involved in it.

The process of the studies revealed correlations between coordinating abilities and psychic properties and processes and confirmed the mutual determination of their development. It is coordinated with fundamental statements of the theory of functional systems that considers the organism as a single whole, which all phenomena and processes are mutually connected and determined [10].

At the same time with present studies of organization-methodical bases of using moving games in physical education of young schoolchildren with PDD [4], the results of these researches specify the structure of general and special means of training coordinating exercises of young schoolchildren with the psychic development delay [8]. The conducted study has a complex character and gives a possibility to understand age and individual peculiarities of children with PDD more detail.

The practical importance of the obtained results is in fact that the offered methodology of training coordinating exercises of young schoolchildren with the psychic development delay may be used in the process of learning-correcting work. Main statements may be used at methodical seminars, qualification improvement courses for teachers of physical training and ones of pedagogical HEIs.

The practical importance is proved by acts of introducing the research results, used as the author methodology of training coordinating exercises of young schoolchildren with the psychic development delay at lessons of physical culture in Lutsk learning-rehabilitative center (of 1.09.2016), at teaching theoretical and practical academic disciplines for students of the department of physical rehabilitation, and used by students at the specialized practice in Lutsk institute of human development of the University "Ukraine" (of 1.09.2016), at elaborating learning programs, at teaching academic disciplines "Defectology bases", "Theory and methodology of physical education" by teachers and pedagogical practice of students of the Eastern European national University, named after Lesya Ukrainka (of 1.09.2016).

The conducted study doesn't pretend for the comprehensive solution of all aspects of the considered problem. We find the perspective of future studies in elaborating and substantiating of the effectiveness of the methodology of the development of coordinating abilities and psychic properties and processes of pupils of middle and senior forms with the psychic development delay.

\section{Conclusions}

1. The study has established that coordinating abilities and psychic properties and processes of young school children with the psychic development delay are at the low level.

2. There has been elaborated the methodology of training coordinating exercises of young schoolchildren with the psychic development delay at lessons of physical culture, directed at optimization of the psychic and physiological development.

3. The forming pedagogical experiment has proved the effectiveness of the experimental methodology of training coordinating exercises of young schoolchildren with the psychic development delay comparing with the conventional one.

4. The revealed positive dynamics of coordinating abilities and psychic properties and processes of young school children with the psychic development delay is a proof of the effectiveness of the experimental methodology of training coordinating exercises of young schoolchildren with the psychic development delay at lessons of physical culture. 


\title{
References
}

[1] Pokamestova, O. V. (2014). Osobennosti detei s zaderzhkoi psikhicheskoho razvitiya (ZPR) v period obucheniya v nachal'noi shkole. Problemy sovremennoi nauki i obrazovaniya, 12 (30), $126-127$.

[2] Illiashenko, T. D., Bastun, N. A., Sak, T. V. (2007). Dity iz zatrymkoiu psykhichnoho rozvytku ta yikh navchannia: navchalnyi posibnyk dlia pedahohiv i shkilnykh psykholohiv. Ministerstvo osvity Ukrainy, Instytut zmistu i metodiv navchannia. Kyiv: IZMN, 128.

[3] Dovhal, V. I. (2013). Naukove obgruntuvannia eksperymentalnoi metodyky zaniat dlia shkoliariv-pidlitkiv iz zatrymkoiu psykhichnoho rozvytku. Fizychne vykhovannia, sport i kultura zdorovia u suchasnomu suspilstvi, 1 (21), 98-102.

[4] Lesko, O. M. (2004). Orhanizatsiyno-metodychni osnovy vykorystannia rukhlyvykh ihor u fizychnomu vykhovanni molodshykh shkoliariv iz zatrymkoiu psykhichnoho rozvytku. Lvivskyi derzhavnyi instytut fizychnoi kultury, 20.

[5] Hvozdetskaia, S. V. (2008). Korrektsiya pokazatelei pamiati u detei 6 let s zaderzhkoi psikhicheskoho razvitiya sredstvami fizicheskoho vospitaniya. Pedahohika, psikholohiya i mediko-biolohicheskie problemy fizicheskoho vospitaniya i sporta, 7, 31-33.

[6] Naboikina, E. (2008). Intehrativnaia korrektsionno-razvivaiushchaia prohramma reabilitatsiyi i adaptatsiyi detei s osobennostiami psikhofizicheskoho razvitiia. Shkol'nyi psikholoh. Izdatel'skiy dom «Pervoe sentiabria», 17, 7-14.

[7] Shmarhun, V. M. (2010). Vikovi ta indyvidualni psykhosomatychni osoblyvosti ditei yak predyktory rozumovoho rozvytku (molodshyi skilnyi i pidlitkovyi vik). Natsionalnyi pedahohichyi universytet imeni M. P. Drahomanova, 39.

[8] Liakh, V. I. (2006). Koordinatsionnye sposobnosti: diahnostika i razvitie. Moscow: TVT Divizion, 290.

[9] Tuchak, O. A., Romaniuk, V. P., Kots, M. O. (2015). Osoblyvosti vzaiemozviazkiv koordynatsiinykh zdibnostei iz psykhichnymy protsesamy ta vlastyvostiamy $\mathrm{v}$ molodshykh shkoliariv iz zatrymkoiu psykhichnoho rozvytku. Fizychne vykhovannia, sport i kultura zdorovia u suchasnomu suspilstvi, 4 (55), 196-200.

[10] Anokhin, P. K. (1980). Uzlovye voprosy teorii funktsional'noi sistemy. Moscow: Nauka, 196.

[11] Bashtan, S. O., Shmaliei, S. V. (2015). Vzaiemozviazok funktsionalnoi ta fizychnoi pidhotovlenosti ditei molodshoho shkilnoho viku z zatrymkoiu psykhichnoho rozvytku. Pryrodnychyi almanakh, 15, 5-13.

\section{THE TRENDS OF CURRENT VOCATIONAL EDUCATION AND TRAINING REFORMS IN LUXEMBOURG: REVIEW AND ANALYSIS}

\author{
Olesia Samokhval \\ Department of Innovation and Information Technologies in Education \\ Vinnytsya Mykhailo Kotsiubynsky State Pedagogical University \\ 32 Ostrozkogo str., Vinnytsia, Ukraine, 21100 \\ samohvallesya@ukr.net
}

\begin{abstract}
The article deals with the theoretical analysis and grounding of current reform trends in the educational system of the Grand Duchy of Luxembourg, particularly in vocational education and training, as well as identifies the backgrounds for reforming the system of vocational education and training, and directions of activity for the implementation of the set tasks. In the course of the study, the problems faced by the Luxembourg vocational education and training were studied. They have both geopolitical and socioeconomic characteristics and comprise: low level of pupils' performance in basic subjects; multilinguism; insufficient coherence of vocational training offers with the needs of the labor market within the country and in Europe; low rate of the labor force, that completes the full range of vocational education and training; insufficient development of vocational training in the tertiary level system.
\end{abstract}

